\title{
NOTES ON THE GEOLOGY, GEOMORPHOLOGY AND SOILS OF THE ALGONKIAN RIVULET-UPPER MAXWELL RIVER AREA, TASMANIAN WILDERNESS WORLD HERITAGE AREA
}

\author{
by Grant Dixon
}

(wirh three text figures)

DIXON, (3., 1992 (31:x): Notes on the geology, geomorphology and soils of the Algonkian Rivulet-upper Maxwell River area, Tasmanian Wilderness World Heritage Area. Pap. Proc. R. Soc. Titm. 126: 13-18. https://doi.org/10.26749/rstpp.126.13 ISSN (0)8(0-470)3. 54 Marlyn Road, South Flobart, Tasmania, Australia 70)(04.

Dolomite, probably Precambrian, occurs throughout the Algonkian and Maxwell valleys. It has been extensively silicified in several areas. The dolomite displays only moderate dips and overlies phyllite and schist, which comprise much of the more elevated parts of rhe region. The phyllite and schist were deformed at least once prior to deposition of the dolomite. Karst features occur extensively in the area, but most are nolonger active. There is considerablevariacion in soils, from acidic peats to those associated with al kaline pans. Alkaline pans are common in the area and observations suggese that, whilst a shore-term phenomenon, they may be recurring features of the landscape.

Key Words: Precambrian dolomite, silicification, karst, alkaline pans, Tasmania.

\section{INTRODUCTION}

The Maxwell River and Algonkian Rivulet are part of the Gordon-Franklin river system. They drain a broad valley, remote and difficult of access, west of the Prince of Wales Range. The valley is littleknown and thickly vegetated, with tall buttongrass heath, closed scrub and forest.

Blake (1936) noted the presence of dolomites, quartzites and schists in the area, and prepared a rudimentary geological map. Corbett \& Brown (1975) noted the occurrence of "comparatively unmetamorphosed Precambrian dolomite" and "pelitic Precambrian metamorphic rocks" in the area, with "undifferentiated Precambrian metamorphic rocks" in the surrounding region.

Cantle (1979) explored several of the depressions, lakes and small caves near Algonkian Rivulet.

Recently a number of Aboriginal archaeological sites have been discovered in dolomite caves in the lower Maxwell Valley (Ranson \& Harris 1986). These notes document observations made during a survey accompanying, and made possible by, an archaeological reconnaissance of the Algonkian Rivulet-upper Maxwell River area during March 1990.

The landscape is generally low and outcrop poor. Outcrop is restricted to a few bluffs (commonly concealed in thick vegetation), creek bed exposures and rare flat-lying areas of bare rock (some associated with alkaline pans). However, the presence of depressions and dolines in many areas is indicative of underlying dolomite.

\section{GEOLOGY}

Most of the low-lying areas of the broad valley of lower Algonkian Rivulet-upper Maxwell River consist of dolomite. The higher surrounding, hills and ridges comprise presumed older Precambrian rocks. A geological map of the area is shown in figure 1.

\section{Older Precambrian Rocks}

These rocks consist of fine-grained purple and greenish phyllites (to the northwest of the area) and quartz-mica schists. A pervasive foliation is ubiquitous, and this appears to have been gently folded. However, at DN132992 a regular crenulation of this foliation was noted and complex, smallscale folds were also observed, both trending east-west.

\section{Massive Dolomite}

This rock is a grey, massive, fine-grained, granular dolomite. Distinct jointing is irregularly developed in some areas, with two distinct subvertical joint trends $\left(220^{\circ}\right.$ and $\left.320^{\circ}\right)$ noted at DN113964. Patches of grainstone occur in some outcrops, and low-angle cross bedding was observed within $0.1-0.3 \mathrm{~m}$ thick, more silty seams. Equivocal stromatolitic laminations occur at DP126000 and DN127964. At DN127964, the dolomite is essentially massive, but sporadic, thin (up to $10 \mathrm{~mm}$ ), silty layers exhibitgradation with respect of dolomite content, and produce differential reliefon weathered surfaces.

Dolomite was briefly examined at two locations further down the Maxwell River valley, DN094788 and DN085877. Here the dolomite is generally similar to the massive dolomite described above, with sporadic banding and rare "graded" silty beds. It dips very slightly south or southeast.

\section{Bedded Dolomite}

This rock is similar to the massive dolomite, but distinct banding, which is probably bedding, is apparent in weathered outcrop. The banding seems to reflect variation in silica content, with layers almost graded in places and variations in relief on weathered surfaces. At DP122001 thin (about $10 \mathrm{~mm}$ ) layers are slightly disrupted (soft sediment deformation?). The contact with the massive dolomite is probably gradational. 


\section{Dolomitic Siltstone}

This rock outcrops extremely poorly and, where exposed, is very weathered. It appears to comprise several of the low ridges on or near the Algonkian-Maxwell watershed.

\section{Quaternary Gravels}

Extensive lowland areas are mantled with surficial deposits of variable thickness up to at least $0.5 \mathrm{~m}$, are well exposed in creek sections and consist of poorly sorted quartzitic and quartz gravels in a sandy or (less commonly) clayey sand matrix. The provenance of the clasts appears to be both the surrounding ranges and the secondary quartz in the dolomites (see below)

\section{Silicification of the Dolomite}

The massive dolomite is silicified in several areas, but the degree can vary considerably, even within a given locality. Quartz occurs as segregations and veins within the dolomite. The quartz fills distinct "fractures", rarely with any consistent orientation, resulting in a "breccia" or "jigsaw" appearance of the rock. The fracture veins are separated by as little as a few centimetres, up to about $0.5 \mathrm{~m}$. The quartz is milky and generally fine-grained, and may be banded or zoned parallel to the vein walls, suggesting distinct phases to deposition accompanying fracture opening. Quartz was also observed, albeit very rarely, as small $(2-3 \mathrm{~mm})$ crystals in vigs in the dolomite. Silicification of the dolomite is pervasive outwards from the veins.

The quartz veining forms an irregular boxwork in the dolomite. This is often spectacularly displayed in the roofs of overhangs and small caves, where the intervening carbonate has weathered out.

Similar occurrences of quartz in dolomite are observed in the Weld Valley-Mr Weld area in southern Tasmania and near Corinna in northwestern Tasmania. In the former case Calver (1989) has suggested they may be remnants of an ancient (Tertiary?) silcrete. Fluid inclusion study of quartz from this area indicates low temperatures of deposition (C.R. Calver, pers. comm.). Silicified dolomite with veining and textures similar to the Algonkian Rivulet area has been described by Piaszczyk (1989) from near Corinna. He considered silicification was produced by a low temperature $\left(<200^{\circ} \mathrm{C}\right)$ fluid probably during late Proterozoic metamorphism.

\section{STRUCTURAL RELATIONSHIPS}

The dolomite strikes generally NE-SW and dips moderately to the southeast in the northern (lower Algonkian) part of the area, and to the northwest or is subhorizontal in the southern (upper Maxwell) part of the area. It is gently folded, but this is rarely apparent in outcrop. Where hinges are observed (e.g. DP 126000), very open folds plunge gently southeast. The dolomite appears unstrained, although jointing has been noted.

Dolomite overlies the older Precambrian rocks with lowangle unconformiry, exposed at DP122004 in the bed of Algonkian Rivulet. No conglomerate, breccia or shearing is evident at the contact, although there is a small "disturbed" area with steeper dips in the phyllite $50 \mathrm{~m}$ to the north.

As noted previously, the older Precambrian rocks have a pervasive foliation, which has itself been folded to some degree. An east-west trending crenulation of this foliation occurs below the unconformity at DP122004. However, the crenulation is not apparent in the overlying, more competenr, bedded dolomite.

No conclusive evidence of facing was observed in the dolomites, but possible grading in some beds near DP123002 suggests they are not overturned. Given the moderate dips, gentle folding and relationship to the older Precambrian rocks, the sequence is unlikely to be overturned.

\section{DISCUSSION OF GEOLOGY}

The unconformable relationship of the dolomite to presumed older Precambrian rocks, low tectonometamorphic grade and comparison with similar rocks elsewhere in Tasmania suggest a late Precambrian age for the dolomitic rocks of the Algonkian-Maxwell valleys.

The lithology and general stratigraphic setting of the Algonkian-Maxwell dolomites suggest correlation with parts of the Weld River Group (Calver 1989), the Jane Dolomite, described from $30 \mathrm{~km}$ north (Spry \& Zimmerman 1959) and the Success Creek Group and correlates in northwestern Tasmania (Williams 1976). These latter sequences have all been correlated at one time or another (Calver 1989, and others). However, unlike the Weld River Group, the Algonkian-Maxwell dolomites unconformably overlie rocks which have experienced at least one cleavageforming event (the Penguin Orogeny?), and so are similar to the Jane Dolomite (as inferred by Spry \& Zimmerman 1959).

Calver (1989) suggested a diminished Penguin Orogeny may have affected the Tyennan region (at least the Weld Valley area), but this appears not to be the case in the Algonkian-Maxwell area.

\section{Karst Features}

Whilst the topography of the area is relatively low-lying, many small, residual hills and small ridges rise abruptly from the lowlands to heights of up to $30 \mathrm{~m}$. A few of these hills consist of older Precambrian rocks but many are dolomite. Bluffs may be developed on such ridges, in places with separated "towers".

Such bluffs are best developed in the more silicified dolomite, in the lower Algonkian valley. It is the location of a number of small caves and shelters or overhangs (including all the Aboriginal archaeological sites discovered during this survey). Such features also appear to be, at least in part, structurally related, with both large shelters in the DP 126000 area occurring in or near the hinge zone of open folds in the dolomite

Elsewhere, karst topography consists of numerous depressions or dolines and small dry or blind valleys, with only sporadic outcrop. These may be subjacent dolines. A larger (probably collapse) doline occurs at DP126000, surrounded by bluffs. Rudimentary rillenkarren morphology is developed on some exposed dolomite surfaces in the lower Algonkian area. The bedded dolomite appears generally less predisposed to the formation of karst features. 


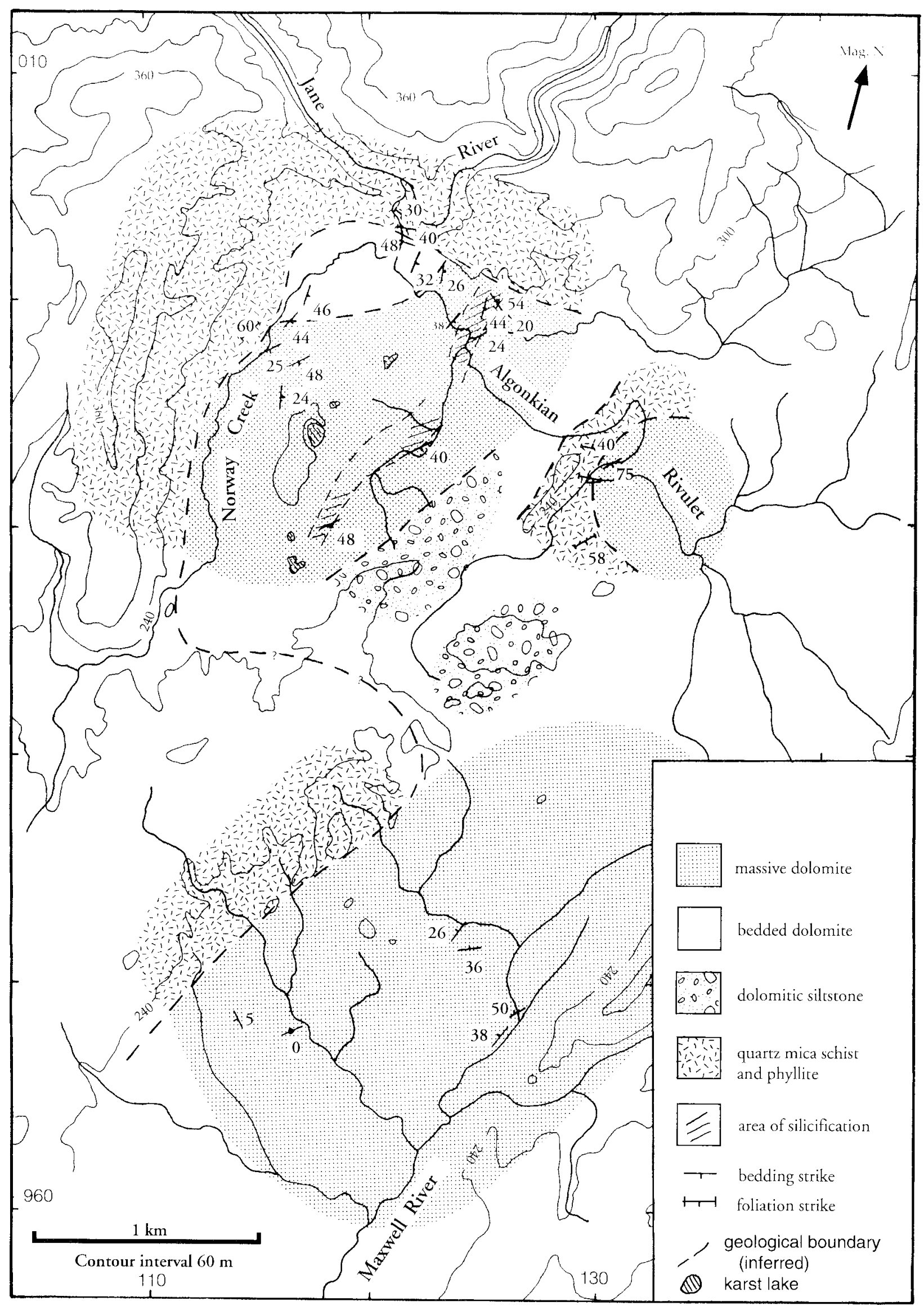

FIG. 1 - Geological map of the Algonkian-Maxwell area. 
The most significant karst features in the area are the lakes siruated on the broad ridge between Algonkian Rivulet and Norway Creek indicated in figure 1. Such karst lakes are rare in Tasmania. There are three large lakes (the largest being $120 \times 70 \mathrm{~m}$ in size) and several small ones. They occur in depressions, the northernmost one complex and uvala-like. The lakes have no apparent outlet, although the northern one (at DN121997) may experience surface drainage to the south during periods of particularly high water. However, the local vegetation suggests this is a rare occurrence. The water level of the larger lakes appears to fluctuate by about $0.5 \mathrm{~m}$, but the occurrence of sphagnum around the margin of the northern lake suggests the water has been at its present low level for several years (J. Whinam, pers. comm.). The lakes appear generally shallow, with deep clayey mud deposits, although the northern one, with steep $20 \mathrm{~m}$ sides forming part of the depression, may have a water depth of several metres.

Pools and flooded dolines occur elsewhere in the Maxwell valley, often intriguingly located atop small hills, suggesting perched water tables, but nowhere else do they have the size or setting of the aforementioned lakes.

The northern lake lies on a line of dolines of various sizes extending northwards towards Algonkian Rivulet. Such doline trends are not uncommon, with the western fall of the ridge east of Norway Creek also partly controlled by such a feature.

Many small, usually subcircular depressions, up to 10 or $15 \mathrm{~m}$ in diameter, occur throughout the area. They are partly infilled by sediment, with evidence they were once water-filled, and are still occasionally inundated. They display sharp discontinuities in the vegetation, with the flat floors occupied by very simple communities including mosses and, in one case, a rare sphagnum.

The lakes and infilled dolines in the area may have considerable potential for palynological studies.

In the upper Maxwell valley, where the dolomite is less silicified and generally flatter-lying, the karst features have a different character. At DN126967 a stream cave more than $30 \mathrm{~m}$ in length, with a partly-phreatic side passage also some $30 \mathrm{~m}$ in length, has developed. The stream sinks in a large collapse doline and flows completely through a small hill. Rudimentary decoration and clastic "microspeleothems" occur.

Well-developed rillenkarren occurs on outcrops in an alkaline pan at DN127964 and on bluffs in the DN1 13964 area. Grikes and small fissure caves also occur in the DN113964 area, development of the former having been controlled by two major sub-vertical joint orientations in the dolomite. The presence of small "foot caves" or notches on the southern side of the bluffs at DN1 13964 suggest higher water levels and/or an alternative course of the adjacent stream in the past.

\section{Drainage Pattern and Geomorphic History}

The reconnaissance nature of the investigations described herein preclude detailed discussion of the geomorphic history of the area, but some general conclusions can be made.

The generally orthogonal drainage pattern, with directions apparently similar to major joint orientations in the dolomite (particularly in the upper Maxwell valley), the observed structural control of many of the karst features and the presence of numerous dolomite residuals suggest that drainage development has probably been controlled by the jointing.

Given the inactive nature of most of the karst features, that dolomite generally occupies the lower parts of the landscape with numerous residuals and that the present drainage is largely surficial, the area is considered to be in "old age" in terms of its geomorphic history. Much karst development probably occurred during Late Pleistocene times, or earlier, with more recent deposition of much of the surficial gravels.

\section{Soils}

Soils in the lower Maxwell valley have been described by Tarvydas (1978), who noted considerable variation in soils and substrates. He noted organic soils (peats), almost entirely fibrous, as the dominant soil, developed over sandy, gravelly and loamy material.

In the Algonkian-Maxwell area there is considerable variation in soils, due mainly to the dolomite bedrock and karst-related environments. The forested areas of older Precambrian bedrock have shallow organic horizons over clay loams, as noted by Pemberton (1989) for his SouthWest land system which includes the surrounding ranges. Skeletal, gravelly soils occur on some ridge crests.

Brown fibrous peat is common throughout the area, occurring beneath both buttongrass heath and closed teatree scrub (the latter with a thick litter layer). In most areas it overlies, or grades into, fine siliceous gravels. Whilst soil $\mathrm{pH}$ (measured in the field with an Inoculo CSIRO test kit) of 3.5-4.5, typical of other parts of southwestern Tasmania (M. Pemberton, pers. comm.), do occur in the area, $\mathrm{pHs}$ of the peats are often around 5.5. This presumably reflects the carbonate bedrock, or at least drainage therefrom. Dark muck peats occur in poorly drained areas.

Other soils noted in the area include alluvial sandy loam ( $\mathrm{pH}$ 5.5-6) occurring along Norway Creek, sandy clay loam $(\mathrm{pH} 4-4.5)$ and pale-brown sand $(\mathrm{pH} 6.5)$ noted in two infilled dolines, black clayey ooze ( $\mathrm{pH} 6)$ and darkbrown clay $(\mathrm{pH} \mathrm{5)}$ occurring adjacent to and beneath the karst lakes, and thin sandy loam ( $\mathrm{pH} 6$ to 6.5 ) occurring on dolomitic siltstone.

Soils on the alkaline pans (see below) consist of thin, cream-coloured, in places clayey, sand with $\mathrm{pH}$ ranging from 7 to 9 .

\section{Alkaline Pans}

Brown et al. (1982) described alkaline pans from the Hardwood River valley. Such pans are also known to occur in the Maxwell and Giblin River valleys and Sandfly Creek area, near Mt Anne (Jarman et al., 1988). Pans in the Giblin and Hardwood valleys are related to limestone bedrock and those in the Maxwell valley and Sandfly Creek areas to dolomite bedrock. Jarman et al. (1988) described two broad classes of vegetation characteristic of pans and suggested that the botanical differences may be related to bedrock type. However, the two types are not always mutually exclusive (op. cit.), as exemplified by some alkaline pans in the upper Maxwell valley (L. Gilfedder, pers. comm.).

The alkaline pans of the Algonkian-Maxwell area are interspersed among more acidic peats, as elsewhere. They are particularly common within an area of some $2 \mathrm{~km}^{2}$ of 
the upper Maxwell valley, south from DN127964, and range in size from a few square metres to more than $800 \mathrm{~m}^{2}$. The pale pans with their sparse, open vegetation contrast sharply with the surrounding buttongrass-heath vegetation, as described by Brown et al. (1982), and so are conspicuous, particularly on aerial photographs.

A feature of all the alkaline pans observed is their location at the foot of steep slopes. In the case of the pan at DN113963, steep slopes occur on all sides of the pan. With the exception of the pan-like area at DN123995 (located on a small creek line) all pans observed are situated immediately adjacent to main drainage lines. Their surfaces are wet and they experience periodic sheet wash, in addition to seepage from the adjacent slopes - often from several directions in the larger, more complexly-shaped pans. The pans occur in areas of dolomite bedrock, with low $(<0.3 \mathrm{~m})$ outcrops in the floor of the larget, better developed pans. Brown et al. (1982) noted reprecipitated carbonate (as concretions on pebbles) in alkaline pans in the Hardwood valley, but no such features were noted on the Algonkian-Maxwell pans. This may be a function of the dolomitic, compared to limestone, bedrock.

The soils of several alkaline pans, or pan-like areas, were examined in the field. An Inoculo CSIRO test kit was used to determine $\mathrm{pH}$.

The pan at DN 127964 is large $\left(>800 \mathrm{~m}^{2}\right)$, irregular in shape and has numerous areas of exposed dolomite bedrock. Soil descriptions in a transect across a typical edge to this pan are given in figure 2 . The spectacular increase in soil $\mathrm{pH}$ ( 4 units over $0.3 \mathrm{~m}$ ) at the edge of the pan is of particular note.

In the major inflow region of the pan described in figure 2 (subject to seepage and periodic sheet wash) is a delta-like area with more than $0.2 \mathrm{~m}$ depth of sandy siliceous gravels $(\mathrm{pH}$ about 6$)$. There is an apparent size sorting to smaller pebbles farther out into the pan. These pebbles are probably reworked from the surrounding surficial deposits.

The pan at DN113963 in the upper Maxwell valley is about $30 \mathrm{~m}$ across and surrounded by steep slopes. Dolomite bedrock is not exposed, and occurs at more than $0.1 \mathrm{~m}$ depth beneath the cream-coloured clayey sand of the pan. There is a distinct surface-water flow from the northwest of the pan, with siliceous gravels concentrated in the southeastern corner. Soil pH (at about $50 \mathrm{~mm}$ depth) is 8-8.5 in the pan centre, $7.5-8$ at the edge, and $7-7.5$ near the inflow area.
Two pan-like areas occur north of an east-west trending dolomite ridge in the DN124995 area. These pans are wetter than those described above, contain small mounds with vegetation more typical of the surrounding peats and soil $\mathrm{pH}$ is somewhat less alkaline. They are incipient pans, possibly undergoing a process of invasion. Brown et al. (1982) suggested alkaline pans are a short-term (albeit up to several hundred years) feature of the landscape, which are slowly infilled by sedimentation and encroached upon by the surrounding peat.

The "pan" at DN124995 (fig. 3) is about $40 \times 10 \mathrm{~m}$ in size and slopes around $4^{\circ}$ to the east. Periodic surface flow occurs downslope, and subsurface seepage occurs from the dolomite ridge to the south. (At the time of observation the local water table was at $0.05 \mathrm{~m}$ depth at $F$ and $0.4 \mathrm{~m}$ depth at B.)

About $100 \mathrm{~m}$ up-valley to the west of the DN124995 (figure 3) "pan" a pan-like area is locared on a drainage line. Cream-coloured sand ( $\mathrm{pH} 7$ ) occurs in the centre of the "pan", brown fibrous sand (pH 5.5-6) at the edge, and dark brown peaty clay loam $(\mathrm{pH} 4.5)$ in the adjacent area (all within a distance of $2 \mathrm{~m}$ ). An algal mat-covered area of the pan has sand with pH 6.5 .

The occurrence of peat berreath the sand of the pan at DN 124995 and the absence of dolomite bedrock at shallow depth suggests that the reasons for the formation and existence of this "pan" may be somewhat different from those of others in the upper Maxwell area, described previously. Brown et al. (1982) suggested pan formation may be initiated by severe peat-burning fires. In the case of the DN 124995 pan, such a fire may have not completely destroyed the now sub-pan peat but promoted alkaline run-off, erosion on slopes and sedimentation from the surrounding area.

Outcrops of dolomite in the large alkaline pan at DN 127964 display two or three "steps", apparently a result of dissolution, up to $0.2 \mathrm{~m}$ above the present pan surface. A one metre high dolomite outcrop protruding from another pan several hundred metres to the southwest shows spectacular undercutting (of up to $0.2 \mathrm{~m}$ ) near its base, also apparently a result of dissolution. As noted previously, Brown et al. (1982) considered alkaline pans to be relatively short-term phenomena in the landscape. However, these dissolution features suggest the pans may also be repeated (in time) features of the landscape, dissolution of the dolomite occurring during previous pan "lives", when they and/or the encroaching peat were at a slightly different level.

peat, with

buttongrass heath $\longrightarrow 1 \longrightarrow$ alkaline pan

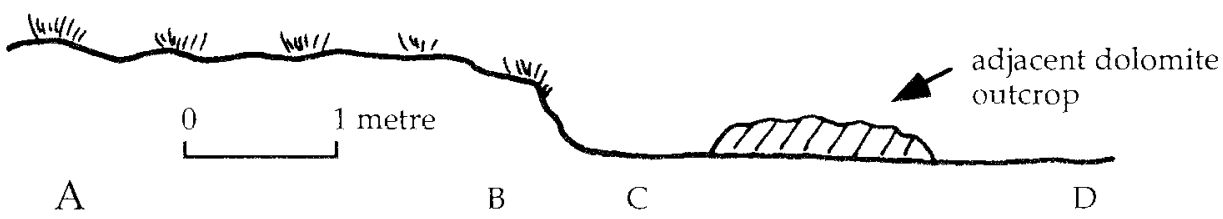

FIG. 2 - Transect across margin of alkaline pan, DN127964. (A) 0.3 m dark-brown, fibrous peat overlying less fibrous, rather organic-rich clay loam, $\mathrm{pH} 3.5$-4. (B) $0.12 \mathrm{~m}$ dark-brown, organic-rich clay loam'peat overlying clay loam with coarse (> $10 \mathrm{~mm}$ ) quartz gravel, pH $4.5(50 \mathrm{~mm}$ depth), 3.5-4 (0.1 m depth). (C) $5 \mathrm{~cm}$ grey-cream-coloured sand on dolomite bedrock, pH 8.5-9. (D) $30 \mathrm{~mm}$ cream-coloured clayey sand on dolomite bedrock, numerous flat siliceous pebbles, pH 8.5-9. 
Plan (sketch), showing location of transect below

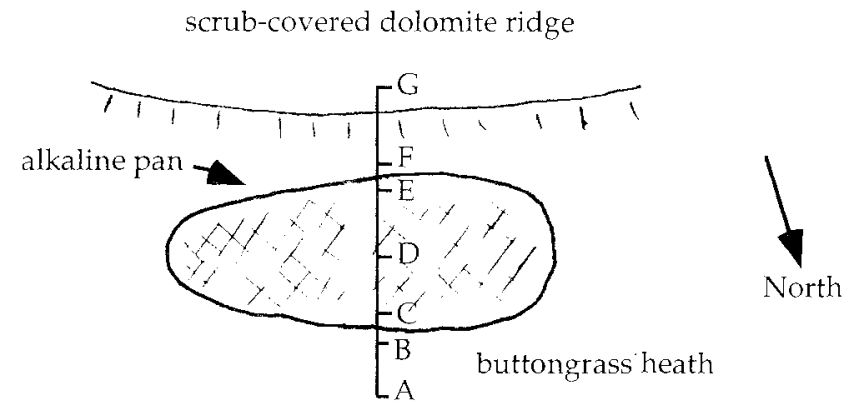

Cross section (sketch)

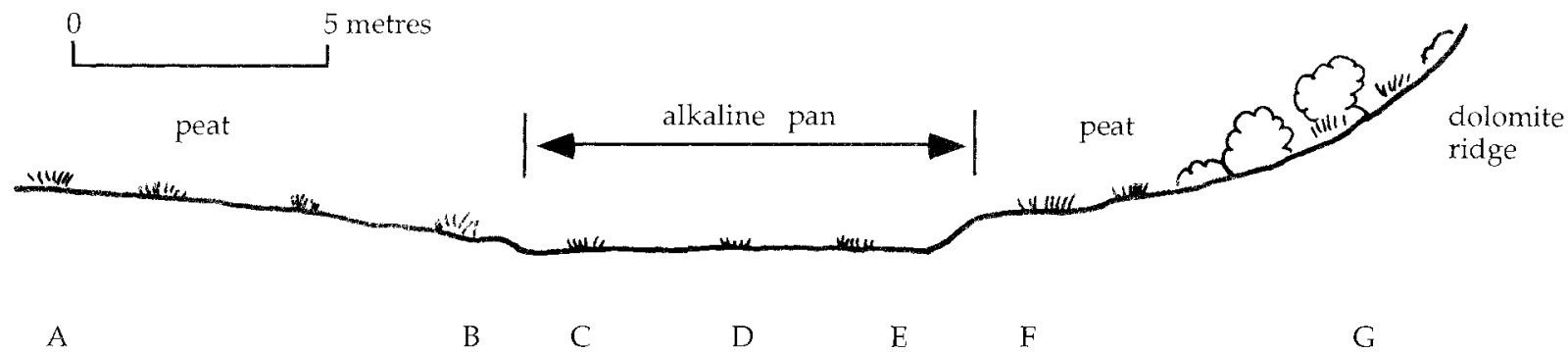

Fig. 3.-Alkaline pan at DN124995. (A) $0.4 \mathrm{~m}$ dark-brown, peaty clay loam with sporadic siliceous gravel, overlying fine siliceous gravels, pH 4 (at $50 \mathrm{~mm}$ and $0.3 \mathrm{~m}$ ). (B) Dark-brown, mucky fibrous peat with minor siliceous gravel, becoming sandy at $0.45-0.5 \mathrm{~m}$ depth, pH 4.5 at $50 \mathrm{~mm}, 5.5-6$ at $0.45 \mathrm{~m}$. (C) $60 \mathrm{~mm}$ cream-coloured sand overlying grey-brown, fibrous, peaty sand, $p H$ 6.5-7. (D) $0.1 \mathrm{~m}$ cream-coloured sand overlying grey, fibrous sandy peat, $p H 7$ at $50 \mathrm{~mm}$. (E) Sandy clay, grading to clay over 20cm, pH 5.5-6. (F) Very dark-brown, mucky fibrous peat with clay, pH 4.5. (G) Brown, fibrous clay loam, becoming less fibrous with depth, pH 5 at $50-100 \mathrm{~mm}, 4$ at $0.5 \mathrm{~m}$ depth.

Therefore, with time, pans may recur in certain locations (perhaps initiated by severe fires, as Brown et al. [1982] suggested), and it follows that their specific location is probably related to local topographic, hydrologic and/or geologic factors.

\section{ACKNOWLEDGMENTS}

I wish to thank the Archaeology section, Department of Parks, Wildlife and Heritage, and particularly Brian Prince, for the opportunity to visit the area. M. Pemberton, M.R.Banks, E.Williams and C.R.Calver are thanked for useful suggestions.

\section{REFERENCES}

Bl.AKF. F., 1936: Report on district between Jane River and Prince of Wales Range. Department of Mines, Geol. Survey Typed Reports.

Brown. M.J., Crowden R.K \& Jarman, S. J., 1982: Vegetation of an alkaline pan-acidic peat mosaic in the Hardwood River Valley, Tasmania. Aust.J.Ecology 7: 3-12.
CAlver, C. R., 1989: The Weld River Group - a major upper Precambrian dolomite sequence in southern Tasmania. Pap Proc. R. Soc, Tasm. 123: 43-54.

CANITE, I., 1979: Jane Rivering. Southern Caver 9: 9-10.

Corbert, K. D. \& Brown, A. V., 1975: Queenstown, Tasmania. Tasm. Dep. Mines 1:250 000 Geol. Atlas Series, sheet SK55/S.

Jarman, S. J., Kanivilas, G. \& Browin, M. J., 1988: Buttongrass moorland in Tasmania. Tas. Forest Research Council, Res. Rep. 2: 50-51.

PIASZCZXK, D., 1989: The characterisation and genesis of the silica flour deposits at Corinna. Unpubl. B.Sc.(Hons.) thesis, Geol. Dep., Univ. of Tasm.

PEMBERTON, M., 1989: LAND SYSTEMS OF TASMANLA REGION 7 - SOUTH WEST. Department of Agriculture, Tasmania.

Ranson, D. \& Harris, S., 1986: Maxwell River archaeological survey. Tasmanian NPWS. Report of survey, National Estate Grant 84/85, No. 8.

Spry, A. \& Zimmerman, D., 1959: The Precambrian rocks of Tasmania, part IV - the Mt. Mullers area. Pap. Proc. R. Soc. Tasm. 93: 1-9.

TARVYDAS, R. K.,1978: LOWER GORDON RIVER SCIENTIFIC SURVEY - SOILS. Hydro-Electric Commission, Tasmania.

WILLIAMS, E., 1976: Explanatory notes for the 1:500 000 structural map of pre-Carboniferous rocks of Tasmania: Tasman Fold Belt system in Tasmania. Tasmanian Dept Mines.

(accepted 3 May 1991) 